\title{
ANALISIS PERBEDAAN ABNORMAL RETURN SEBELUM DAN SESUDAH PENGUMUMAN JAKARTA ISLAMIC INDEX
}

\author{
Edi Setiyawan', Ari Kristin Prasetyoningrum ${ }^{2}$, Dessy Noor Farida ${ }^{3}$ \\ ${ }^{1,2,3}$ Fakultas Ekonomi dan Bisnis Islam, UIN Walisongo \\ 1 edisetiyawan@outlook.co.id \\ 2ari_kristin@walisongo.ac.id \\ ${ }^{3}$ dessy_nf@walisongo.ac.id
}

\begin{abstract}
ABSTRAK
Tujuan penelitian ini adalah untuk menganalisis perbedaan rata-rata abnormal return pada saham JII sebelum dan sesudah peristiwa masuk JII, dan sebelum dan sesudah peristiwa keluar JII pada periode 2012 sampai dengan 2017. Penelitian ini menggunakan event study dengan melakukan pengamatan terhadap rata-rata abnormal return saham selama 7 hari sebelum (pre event), hari peristiwa event date, dan 7 hari setelah (post event) peristiwa pengumuman perubahan komposisi JII periode 2012 sampai 2017. Penelitian ini menggunakan data sekunder. Data yang digunakan dalam penelitian ini meliputi harga penutupan saham harian dan nilai penutupan JII. Expected return menggunakan model market-adjtusted-model. Sedangkan sampel yang digunakan adalah saham-saham yang termasuk dalam daftar JII pada Bursa Efek Indonesia. Hasil penelitian menunjukkan uji statistik terhadap abnormal return selama periode peristiwa tidak ditemukannya rata-rata abnormal return yang signifikan pada peristiwa masuk dan keluarnya saham-saham pada JII . Hal ini mengindikasikan bahwa kondisi pasar sudah efisien bentuk setengah kuat, investor tidak bisa mendapatkan abnormal return dengan memanfaatkan informasi baru yang ada, dimana sudah tidak terjadi asimetris informasi, terlihat dari reaksi investor pada t0 dan $\mathrm{t}+1$ baik itu pada saham yang masuk dan saham yang keluar JII walaupun terdapat kebocoran informasi pada $\mathrm{t}-1$ sudah ada reaksi investor.
\end{abstract}

Kata kunci : average abnormal return, event study, jakarta islamic index

\begin{abstract}
The purpose of this study was to analyze the difference in the average abnormal return on JII shares before and after the JII entry event, and before and after the JII exit event in the period 2012 to 2017. This study uses event study by observing the average abnormal return stock for 7 days before (pre event), event date event, and 7 days after (post event) announcement event changes in composition JII period 2012 to 2017. This study uses secondary data. The data used in this study include the daily closing price of shares and closing value of JII. Expected return uses a market-adjtusted-model model. While the samples used are stocks included in the JII list on the Indonesia Stock Exchange. The results of the study show that statistical tests on abnormal returns during the event period did not find a significant average abnormal return in the events of the entry and exit of shares at JII. This indicates that the market conditions are efficient in the form of halfstrong, investors cannot get an abnormal return by utilizing existing information, where asymmetric information has not occurred, it can be seen from the reaction of investors at to and $t+1$ both in the incoming shares and shares Even if there is an information leak on $t-1$, there is an investor reaction.
\end{abstract}

Keywords: average abnormal return, event study, jakarta islamic index 


\section{PENDAHULUAN}

Suatu pasar modal dikatakan berkembang atau tidak, salah satu faktornya adalah ditandai dengan tersedianya informasi secara luas dan mudah diakses yang dapat dijadikan investor sebagai bahan pertimbangan dalam pemilihan instrumen investasi, dalam pasar yang sudah efisien keberhasilan suatu emiten dilihat dari nilai harga sahamnya, karna pasar yang efisien dapat menunjukkan harga saham yang mencerminkan secara penuh informasi yang tersedia, informasi tersebut dapat berupa laporan tahunan, pembagian dividen, stock split dan sebagainya (Nasution, 2015).

Salah satu faktor yang mendukung kepercayaan investor adalah persepsi mereka terhadap kewajaran harga saham (sekuritas), pasar modal di katakan efisien secara informasi apabila harga saham yang ada di pasar mencerminkan semua informasi yang relevan, apabila informasi yang terserap ke calon investor semakin cepat dan tepat dan tercermin pada harga saham, maka pasar modal semakin efisien, dalam pandangan prinsip syariah yang mengedepankan informasi yang benar, karna pasar yang efisien menciptakan keadilan sehingga memberikan kebaikan untuk para investor (Nasution, 2015).

Jakarta Islamic Index merupakan salah satu indeks yang terdapat pada bursa efek Indonesia (BEI) berdasarkan prinsip syariah yang diluncurkan pertama kali pada tanggal 3 Juli 2000 (Jogiyanto, 2010). Masuknya suatu saham ke dalam Jakarta Islamic Index, merupakan sentimen positif bagi investor, karena akan membuat investor lebih percaya dalam menginvestasikan dananya di perusahaan tersebut. Selain itu, bagi perusahaan sendiri, akan lebih mudah dalam mendapatkan dana, yang dengan dana tersebut perusahaan dapat mengembangkan usaha lebih luas lagi. Namun, di sisi lain keluarnya sebuah perusahaan dalam sebuah indeks akan menurunkan kepercayaan investor karena menganggap bahwa perusahaan sudah tidak sesuai dengan syariah dan tidak konsisten.

Hal tersebut merupakan reaksi investor terhadap informasi baru yang muncul. Di jelaskan lebih lanjut mengenai kecepatan penyesuaian (speed adjustment) dari harga sekuritas karna penyebaran informasi terjadi dengan cepat setelah informasi keluar dan menjadi tersedia bagi semua orang, pasar dikatakan efisien jika waktu penyesuaian harga ekuilibrium berjalan dengan cepat (Jogiyanto, 2010).

Namun jika waktu penyesuaian harga memerlukan watu yang lama sampai berlarut-larut maka mengindikasikan informasi yang tidak terdistribusi secara simetris, atau informasi hanya diketahui oleh beberapa orang saja yang menandakan terjadinya asimetris informasi yang menghambat terjadinya pasar efisien. Jika suatu peristiwa mengandung informasi maka pasar akan bereaksi, dan akan di respons pasar yang ditunjukkan oleh adanya Abnormal return (Jogiyanto, 2010).

Dalam jurnal penelitian menyimpulkan bahwa terdapat abnormal return positif dan signifikan di sekitar pengumuman perubahan komposisi Jakarta Islamic Index yang menandakan bahwa pengumuman perubahan komposisi Jakarta Islamic Index mempengaruhi return saham (Oktaviana \& Wahyuni, 2011). Namun dari penelitian yang dilakukan oleh rahman hakim menghasilkan kesimpulan yang berbeda yakni diperoleh akumulasi rata-rata abnormal return yang tidak signifikan pada 5 hari sebelum dan 1 hari setelah pengumuman perubahan komposisi Jakarta Islamic Index (Hakim, 2015). 
Penelitian yang dilakukan oleh Dwi Sari, menghasilkan kesimpulan bahwa tidak terdapat perbedaan yang signifikan pada return dan aktivitas volume perdagangan saham sebelum dan sesudah pengumuman perubahan komposisi Indeks Sri-kehati pada semua periode penelitian (Dwi Sari, 2016).

Tabel 1. Perbandingan hasil penelitian terdahulu

\begin{tabular}{|c|c|c|c|c|}
\hline Peneliti & Peristiwa & Variabel & $\begin{array}{c}\text { Metode } \\
\text { penelitian }\end{array}$ & $\begin{array}{c}\text { Tanda Abnormal } \\
\text { return }\end{array}$ \\
\hline $\begin{array}{c}\text { Oktaviani dan } \\
\text { Wahyuni (2012) }\end{array}$ & $\begin{array}{c}\text { Perubahan } \\
\text { komposisi jii }\end{array}$ & $\begin{array}{c}\text { Abnormal } \\
\text { return, trading } \\
\text { volume activity }\end{array}$ & Event study & + \\
\hline Mahar (2014) & $\begin{array}{c}\text { Perubahan } \\
\text { komposisi } \\
\text { LQ45 }\end{array}$ & $\begin{array}{c}\text { Abnormal } \\
\text { return, trading } \\
\text { volume activity }\end{array}$ & Event study & + \\
\hline Hakim (2015) & $\begin{array}{c}\text { Perubahan } \\
\text { komposisi jii }\end{array}$ & $\begin{array}{c}\text { Abnormal } \\
\text { return }\end{array}$ & Event study & 0 \\
\hline Dinianto (2012) & $\begin{array}{c}\text { Perubahan } \\
\text { komposisi } \\
\text { indeks sri- } \\
\text { kehati }\end{array}$ & $\begin{array}{c}\text { return. } \\
\text { Trading } \\
\text { volume activity }\end{array}$ & Event study & 0 \\
\hline
\end{tabular}

Notasi $=(+)$ terdapat abnormal return yang signifikan (0) tidak terdapat abnormal return yang signifikan

Dari penelitian di atas ditemukannya hasil yang tidak konsisten mengenai penelitian Abnormal return. Pada penelitian Oktaviana \& Wahyuni (2011) di temukannya abnormal return yang signifikan. Hal senada juga di sampaikan dalam penelitian Mahar yang menghasilnya adanya abnormal return dan trading volume activity yang signifikan pada sekitar waktu pengumuman yang sesuai dengan teori Markets efficient yaitu pasar akan segera mengoreksi harga saham pada saat ada informasi yang keluar ke publik yang di tunjukan dengan adanya reaksi pasar (Krichene, 2013).

Namun, hasil berbeda yang ditemukan oleh Hakim dan Dinianto yang mana pada hasil penelitiannya tidak terdapat abnormal return dan trading volume activity yang signifikan yang menandakan bahwa pengumuman tersebut tidak mengandung informasi yang tidak sesuai dengan teori Market efficient (Hakim, 2015).

Berdasarkan pemaparan di atas, terdapat perbedaan kesimpulan antara penelitian yang satu dengan penelitian yang lainya, selain itu juga masih sedikit peneliti yang melakukan penelitian mengenai pasar efisien terutama dalam Jakarta Islamic Index. Oleh sebab itu Tujuan penelitian ini adalah untuk menguji kandungan informasi pada Jakarta Islamic Index periode 2012-2017.

\section{TINJAUAN PUSTAKA DAN PENGEMBANGAN HIPOTESIS}

\section{Pasar Efisien}

Konsep dasar pasar efisien di kemukakan dan dipopulerkan pertama kali oleh Eugene F Fama dalam jurnalnya yang berjudul "Efficient Capital Markets: A Review Of Theory And Empirical Work", pasar dikatakan efisien apabila harga- 
harga yang ada sepenuhnya mencerminkan (fully reflect) semua informasi yang ada (Fama et al., 1991). Sedangkan menurut Krichene (2013) pasar efisien yaitu ketika tidak adanya biaya transaksi yang kenakan kepada investor atau trader. Suatu pasar dikatakan efisien apabila tidak seorang pun baik itu investor ritel, maupun institusi akan mampu memperoleh return tidak normal (abnormal return) setelah di sesuaikan dengan risiko dengan menggunakan strategi yang ada (Gumanti \& Utami, 2002).

Menurut Fama bentuk pasar efisien dapat dikelompokkan menjadi tiga yang di kenal dengan hipotesis pasar efisien (efisien maket Hypothesis) ketiga bentuk yang di maksud adalah: bentuk lemah (weak form of the efisien maket hypotesis), bentuk setengah kuat (semi strong form of the efisien maket hypotesis), bentuk kuat (stong form of the efisien maket hypotesis), setiap bentuk pasar efisien menggambarkan sejauh mana informasi di serap oleh pasar (Fame, 2010). Dikutip dari (Gumanti \& Utami, 2002), penjelasan dari ketiga bentuk pasar efisien akan di jelaskan sebagai berikut:

- Hipotesis pasar efisien bentuk lemah

Dalam hipotesis ini diasumsikan bahwa harga saham mencerminkan semua informasi masa lalu (historical) yang berkaitan dengan harga saham yang bersangkutan yang sudah terjadi. Dan informasi masa lalu tersebut tidak bisa digunakan sebagai strategi investasi atau trading karna harga bergerak dalam bentuk acak (random walk). Dengan demikian segala jenis strategi menggunakan analisa teknikal tidak akan mampu mendapatkan abnormal return.

- Hipotesis pasar efisien bentuk semi kuat

Dalam artikel yang lain, Fama menyebutkan bahwa pasar efisien semi kuat sebagai studi peristiwa (Event study) yang artinya harga-harga sekuritas mencerminkan semua informasi publik yang relevan. Sehingga dalam hipotesis pasar semi kuat ini di samping merupakan cerminan harga saham historis, harga yang tercipta juga karna di pengaruhi oleh informasi yang ada di pasar, termasuk di dalamnya laporan keuangan atau informasi pendukung lainya termasuk suku bunga dan rating perusahaan (Fama et al., 1991).

- Hipotesis pasar efisien bentuk kuat

Hipotesis pasar efisien bentuk kuat ini, semua faktor-faktor pasar efisien bentuk lemah dan bentuk setengah kuat Include di dalamnya selain itu juga terdapat faktor informasi privat, hipotesis pasar efisien bentuk kuat semua informasi yang tersedia sepenuhnya tercermin dalam harga baik itu informasi publik maupun informasi privat selain itu juga tidak ada individu yang memiliki keuntungan perdagangan yang lebih tinggi dari investor yang lain karna dia memiliki akses monopoli untuk beberapa informasi. Sehingga walaupun dia memiliki informasi privat, dalam efisien bentuk kuat dia bisa mendapatkan abnormal return (Fama et al., 1991).

\section{Studi Peristiwa}

Dalam bukunya, Jogiyanto (2010) menyatakan bahwa studi peristiwa (Event study) sering disebut juga dengan nama analisis residual (residual analysis) atau pengujian indeks kinerja tak normal (Abnormal Performance Index test) atau pengujian reaksi pasar (maket reaction test). Kemudian Jogiyanto mengutip pernyataan Bowmen 
(1983) mendefinisikan suatu studi peristiwa sebagai studi yang melibatkan analisis perilaku harga sekuritas sekitar waktu suatu kejadian atau pengumuman informasi.

\section{Return taknormal (Abnormal Return)}

Return (kembalian) adalah tingkat keuntungan yang dinikmati oleh pemodal atas suatu investasi yang dilakukannya ("reaksi signal rasio terhadap return," n.d.) (Susilowati \& Turyanto, 2011).

- Expected Return (Market Adjusted Model)

$\mathrm{E}\left(\mathrm{R}_{\mathrm{i}, \mathrm{t}}\right)=\mathrm{R}_{\mathrm{M}, \mathrm{t}}$

Keterangan :

$\mathrm{E}\left(\mathrm{R}_{\mathrm{i}, \mathrm{t}}\right) \quad=$ return ekspektasi sekuritas ke-i periode peristiwa ke-t

$\mathrm{R}_{\mathrm{M}, \mathrm{t}} \quad=$ return pasar dari sekuritas ke-i periode peristiwa ke-t

- Actual return

keterangan:

$$
R i, t=\frac{P_{i, t}-P_{i, t-1}}{P_{i, t-1}}
$$

$\mathrm{R}_{\mathrm{i}, \mathrm{t}} \quad=$ Pendapatan aktual return untuk saham i pada bulan $\mathrm{t}$

$\mathrm{P}_{\mathrm{i}, \mathrm{t}} \quad=$ Harga saham i pada bulan $\mathrm{t}$

$\mathrm{P}_{\mathrm{i}, \mathrm{t}-1}=$ Harga saham i pada bulan $\mathrm{t}-1$

- Abnormal return

Keterangan :

$$
R T N_{i-\mathrm{t}}=R_{i, t}-E\left(R_{i, t}\right)
$$

$R T N_{i-\mathrm{t}}=$ return tak normal saham i pada waktu $\mathrm{t}$

$R_{i, t} \quad=$ return realisasi pada saham i pada waktu $\mathrm{t}$

$E\left(R_{i, t}\right)=$ return yang diharapkan saham i pada waktu $\mathrm{t}$

\section{Teori Asimetris}

Dalam pasar efisien, jika reaksi pasar membutuhkan waktu lama dalam bereaksi terhadap suatu informasi atau peristiwa, sampel berlarut-larut dan cukup lama, hal ini mengindikasikan bahwa adanya distribusi informasi yang belum simetris, sehingga hanya beberapa investor saja yang mendapatkan informasi sehingga investor yang mendapatkan informasi ini dapat mendapatkan return yang tidak normal (abnormal return) (Haryono, 2015).

Menurut Jogiyanto ada 4 penjelasan yang mendasari penyebaran informasi asimetris menjadi informasi yang simetris, antara lain yaitu Informasi privat yang disebarkan secara resmi ke publik melalui pengumuman oleh perusahaan, investor yang memiliki informasi privat akan menggunakannya dan kemudian mereka akan bersedia menjualnya, Investor yang mendapatkan informasi secara privat akan melakukan tindakan spekulatif (spekulatif behavior), dalam teori ekspektasi rasional (rasional expetation theory), yang menjelaskan bahwa investor yang tidak mendapatkan informasi privat, akan mendapatkan informasi tersebut lewat pengamatan perubahan harga yang terjadi, dengan cara mengamati perubahan harga yang terjadi 
kemudian investor akan melakukan transaksi dengan mengikuti transaksi yang dilakukan oleh investor yang mempunyai informasi (Jogiyanto, 2010).

\section{Jakarta Islamic Index}

Jakarta Islamic Index merupakan Index yang terdiri dari 30 saham yang sudah sesuai Syariah, yang penentuannya di lakukan oleh dewan Syariah nasional majelis ulama Indonesia (DSN-MUI). Saham-saham yang masuk ke dalam Indeks Syariah adalah emiten yang kegiatan usahanya tidak bertentangan dengan syariah Islam (Dewan Syariah Nasional, 2003) seperti:

- Usaha perjudian dan permainan yang tergolong judi atau perdagangan yang di larang.

- Usaha lembaga keuangan konvensional (ribawi) termasuk didalam-Nya perbankan dan asuransi konvensional.

- Usaha yang memproduksi, mendistribusi serta memperdagangkan makanan dan minuman yang tergolong haram.

- Usaha yang memproduksi, mendistribusi dan atau menyediakan barang ataupun jasa yang merusak moral dan bersifat mudarat.

- Selain penyeleksian di atas, kemudian dilakukan seleksi berikutnya yaitu dengan mempertimbangkan aspek likuiditas dan kondisi keuangan emiten, antara lain:

- Memilih kumpulan saham dengan jenis usaha utama yang tidak bertentangan dengan prinsip syariah dan sudah di catat lebih dari 3 bulan (kecuali termasuk ke dalam 10 kapitalisasi besar).

- Memilih saham berdasarkan laporan keuangan tahunan atau tengah tahun berakhir yang memiliki rasio kewajiban terhadap aktiva maksimal $90 \%$.

- Memilih 60 saham dari susunan saham di atas berdasarkan urutan rata-rata kapitalisasi pasar (maket capitalization) terbesar selama satu tahun terakhir.

- Memilih 30 saham dengan urutan berdasarkan tingkat likuiditas rata-rata nilai perdagangan reguler selama satu tahun terakhir.

Pengkajian ulang akan dilakukan 6 bulan sekali dengan penentuan komponen indeks pada awal bulan Januari dan Juli setiap tahunya. Sedangkan perubahan pada jenis usaha emiten akan di monitoring secara terus menerus berdasarkan data-data publik yang tersedia (Darmadji \& Fakhrudin, 2008).

\section{METODE PENELITIAN}

Penelitian ini menggunakan event study dengan periode jendela 15 hari, yaitu dari $\mathrm{t}-7$ sampai $\mathrm{t}+7$ yang terdiri dari $\mathrm{t}-7$ sebelum pengumuman (pre event), $\mathrm{t} 0$ sebagai hari terjadinya pengumuman (event date), dan $\mathrm{t}+7$ sebagai hari setelah pengumuman (post event).

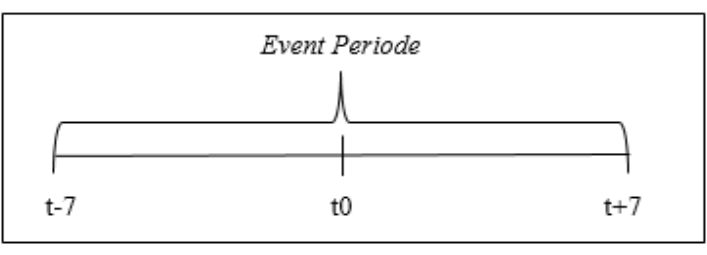

Periode jendela 15 hari $t-7, t 0, t+7$ 
Data yang digunakan adalah data data yang diperoleh dalam bentuk yang sudah jadi, sudah di kumpulkan di diolah oleh pihak lain yang biasanya sudah dalam bentuk publikasi seperti pada Bursa Efek Indenesia, Investing, dan lainya (Hendrayadi, 2015). Populasi yang digunakan adalah terutama saham-saham perusahaan yang terdaftar dalam Jakarta Islamic Indeks pada periode bulan Juni 2012 sampai bulan November 2017, sedangkan sampel yang digunakan dalam penelitian ini menggunakan kriteria sebagai berikut:

1. Perusahaan yang masuk dan keluar dari Jakarta Islamic Indeks selama periode 2012-2017.

2. Perusahaan terbebas dari peristiwa pengganggu (confounding effect) yang terjadi pada internal perusahaan pada periode jendela seperti pengumuman pembagian dividen, stock split dan right issue..

3. Perusahaan memiliki data historical price yang lengkap selama periode 20122017.

4. Aktif di perdagangkan di bursa

Teknik pengumpulan yang digunakan adalah dengan mengumpulkan data baik yang tercetak maupun elektronik. Sedangkan metode analisis statistic yang dipakai adalah uji shapiro wilk-Test untuk menguji normalitas data (Kurtosis, n.d.) dan menggunakan uji beda berpasangan (paired sample t-test) yang digunakan untuk menguji hipotesis, yaitu metode yang digunakan untuk membandingkan rata-rata dua sampel yang saling berhubungan dalam satu kelompok penelitian.

1. Pengujian Hipotesis

a. Pengujian $\mathrm{H} 1$ dan $\mathrm{H} 2$

Untuk mengetahui apakah terdapat abnormal return di sekitar tanggal keterangan:

$\mathrm{R}_{\mathrm{i}, \mathrm{t}} \quad=$ Pendapatan aktual return untuk saham i pada bulan $\mathrm{t}$

$\mathrm{P}_{\mathrm{i}, \mathrm{t}} \quad=$ Harga saham $\mathrm{i}$ pada bulan $\mathrm{t}$

$\mathrm{P}_{\mathrm{i}, \mathrm{t}-1}=$ Harga saham i pada bulan $\mathrm{t}-1$

1. Menghitung abnormal return

$$
R T N_{i-\mathrm{t}}=R_{i, t}-E\left(R_{i, t}\right)
$$

Keterangan :

$R T N_{i-\mathrm{t}} \quad=$ return tak normal saham i pada waktu $\mathrm{t}$

$R_{i, t} \quad=$ return realisasi pada saham i pada waktu $\mathrm{t}$

$E\left(R_{i, t}\right)=$ return yang diharapkan saham i pada waktu $\mathrm{t}$

2. Menghitung average abnormal return $(A A R)$ untuk setiap periode kejadian pengumuman JII, menggunakan langkah-langkah sebagai berikut:

3. Menghitung expected return (Market Adjusted Model)

$\mathrm{E}\left(\mathrm{R}_{\mathrm{i}, \mathrm{t}}\right)=\mathrm{R}_{\mathrm{M}, \mathrm{t}}$

Keterangan :

$\mathrm{E}(\mathrm{Ri}, \mathrm{t})=$ return ekspektasi sekuritas ke-i periode peristiwa ke-t

$\mathrm{R}_{\mathrm{M}, \mathrm{t}} \quad=$ return pasar dari sekuritas ke-i periode peristiwa ke-t 
4. Actual return

$$
R i, t=\frac{P_{i, t}-P_{i, t-1}}{P_{i, t-1}} \quad \mathrm{AAR}_{\mathrm{i}, \mathrm{t}}=\frac{\sum_{i=1}^{k} \mathrm{AR}_{\mathrm{i}, \mathrm{t}}}{k}
$$

Keterangan :

$\mathrm{AARi}, \mathrm{t}=$ rata-rata abnormal return sekuritas ke-i pada hari ke-t

$\mathrm{ARi}, \mathrm{t}=$ abnormal return untuk sekuritas ke-i pada hari ke-t

$\mathrm{K}=$ jumlah sekuritas

5. Menentukan kriteria pengujian hipotesis

Hol diterima jika sig $-\mathrm{t}$ (probabilitas) $<0,05$ atau $\mathrm{t}$ hitung $=\mathrm{t}$ tabel atau $-\mathrm{t}$ hitung $=-\mathrm{t}$ tabel.

Ho2 diterima jika sig $-\mathrm{t}$ (probabilitas) $<0,05$ atau $\mathrm{t}$ hitung $=\mathrm{t}$ tabel atau $-\mathrm{t}$ hitung $=-\mathrm{t}$ tabel.

6. Menarik kesimpulan hasil pengujian hypotesis

\section{HASIL DAN PEMBAHASAN}

Penelitian ini menguji kandungan informasi (information content) pada pengumuman JII. Khususnya pada saham-saham yang masuk ke JII dan saham-saham yang keluar dari JII pada periode 2012-2017. Tujuan penelitian ini adalah untuk mengkaji apakah pasar bereaksi dengan segera merespon informasi baru yang muncul (JII). Reaksi terhadap kandungan informasi diukur menggunakan avearge abrnormal return (AAR) di sekitar jendela peristiwa.

\section{Analisis Statistik}

Tabel 5. Hasil Perhitungan AAR (Average Abnormal Return ) per Tanggal Periode Jendela Pengamatan

\begin{tabular}{|c|r|r|}
\hline Hari Ke t & AAR masuk & AAR keluar \\
\hline-7 & $-0,0031$ & $-0,0030$ \\
\hline-6 & 0,0110 & 0,0038 \\
\hline-5 & 0,0042 & $-0,0027$ \\
\hline-4 & $-0,0021$ & 0,0025 \\
\hline-3 & 0,0026 & $-0,0024$ \\
\hline-2 & $-0,0044$ & $-0,0004$ \\
\hline-1 & 0,0008 & $-0,0048$ \\
\hline $\mathbf{0}$ & $\mathbf{0 , 0 0 6 9}$ & $\mathbf{- 0 , 0 0 7 9}$ \\
\hline+1 & 0,0145 & 0,0063 \\
\hline+2 & 0,0096 & $-0,0101$ \\
\hline+3 & $-0,0012$ & $-0,0045$ \\
\hline+4 & $-0,0029$ & 0,0016 \\
\hline+5 & 0,0022 & 0,0083 \\
\hline+6 & $-0,0037$ & 0,0005 \\
\hline+7 & 0,0076 & 0,0029 \\
\hline
\end{tabular}

Sumber : hasil olah data sekunder (2018) 
Dari tabel 5 di atas, diketahui bahwa pada AAR masuk yang bernilai positif ada pada $\mathrm{t}-6, \mathrm{t}-5, \mathrm{t}-3, \mathrm{t}-1$, untuk sebelum masuk, $\mathrm{t} 0$ dan $\mathrm{t}+1, \mathrm{t}+2, \mathrm{t}+5, \mathrm{t}+7$ untuk setelah masuk. Pada AAR keluar yang bernilai positif ada pada $\mathrm{t}-6, \mathrm{t}-4, \mathrm{t}+1, \mathrm{t}+4, \mathrm{t}+5, \mathrm{t}+6, \mathrm{t}+7$.

Setelah mengetahui abnormal return yang sudah di reratakan per tanggal periode jendela penelitian, maka dapat dilakukan uji normalitas kemudian di lanjutkan uji hipotesis dengan membandingkan masing-masing abnormal return dengan uji beda (uji komparasi) rata-rata dua sampel (paired sample T-test).

\section{Analisis Statistik Deskriptif}

Uji ini memuat deskriptif statistik mengenai jumlah perubahan komposisi Jakarta Islamic Index yang di jadikan sampel hasil proses screening dan sudah melalui tahap perhitungan expected return, actual return, abnormal return dan kemudian di rata-rata kan $(A A R)$ untuk tiap event date penelitian. Hasil pengujian yang telah dilakukan dapat dilihat pada tabel 2.1 di bawah ini.

Tabel 6. Statistik Deskriptif Minimum, Maksimum, Mean dan

Standar Deviasi

\begin{tabular}{|l|r|r|r|r|r|}
\hline \multicolumn{7}{|c|}{ Descriptive Statistics } \\
\hline & $\mathrm{N}$ & Minimum & \multicolumn{1}{c|}{ Maximum } & \multicolumn{1}{c|}{ Mean } & Std. Deviation \\
\hline pengumuman masuk & 15 & $-0,0044$ & 0,0145 & 0,0028 & 0,005964 \\
\hline pengumuman keluar & 15 & $-0,0101$ & 0,0083 & $-0,00066$ & 0,005098 \\
\hline Valid N (listwise) & 15 & & & & \\
\hline
\end{tabular}

Pada tabel 6. di atas dapat diketahui bahwa variabel pengumuman masuk dan pengumuman keluar memiliki nilai $\mathrm{N}$ sebesar 15 , nilai ini merupakan variabel penelitian yang sama dengan event date yaitu 15 hari. Variabel pengumuman masuk memiliki nilai terendah sebesar -0,0044 dan nilai tertinggi sebesar 0,0145 dengan nilai rata ratanya sebesar 0,0028 dan standar deviasinya (tingkat sebaran data) sebesar 0,0059 . Variabel pengumuman keluar memiliki nilai minimum sebesar $-0,0101$ dan nilai tertinggi sebesar 0,0083 dengan nilai rata ratanya sebesar $-0,0006$ dengan nilai standar deviasinya sebesar 0,005 .

\section{Pengujian Normalitas}

Uji normalitas digunakan untuk mengetahui apakah data untuk masing-masing variabel terdistribusi normal atau tidak. Uji normalitas yang pertama yaitu menguji data AAR(Average abnormal return) pada saham yang sebelum dan sesudah masuk Jakarta Islamic Index periode 2012-2017.

Tabel 7.1 Uji Normalitas AAR Saham Sebelum dan Sesudah Perusahaan

Masuk Dalam Jakarta Islamic Index Periode 2012-2017

\begin{tabular}{|c|c|c|c|}
\hline \multicolumn{4}{|c|}{ Test of Normality } \\
\hline & \multicolumn{3}{|c|}{ Shapiro-Wilk } \\
\hline & Statistic & df & Sig. \\
\hline sebelum_masuk & 0,927 & 7 & 0,522 \\
\hline sesudah_masuk & 0,92 & 7 & 0,471 \\
\hline \multicolumn{4}{|c|}{ *. This is a lower bound of the true significance. } \\
\hline \multicolumn{4}{|c|}{ a. Lilliefors Significance Correction } \\
\hline
\end{tabular}

Sumber: Hasil olah data menggunakan SPSS (2018) 


\section{Interpretasi}

Dari hasil uji normalitas didapatkan hasil bahwa dari nilai sig dalam pengujian Shapirowilk, sebagai berikut:

a. sebelum masuk memiliki nilai sig 0,522

b. setelah masuk memiliki nilai sig 0,471

jika :

sig $<0,05$ tidak signifikan

sig $>0,05$ signifikan

maka :

a. sebelum masuk sig $0,522>0,05$

b. setelah masuk sig 0,471>0,05

Dari hasil uji statistik di atas terlihat bahwa pada nilai sig a dan b memiliki nilai lebih besar dari 0,05 yakni 0,522 untuk nilai sebelum masuk dan 0,471 untuk nilai setelah masuk, karna kedua nilai tersebut lebih besar daris 0,05 sehingga dapat dikatan bahwa kedua variabel di atas yaitu $A A R$ sebelum masuk Jakarta Islamic Index, dan $A A R$ setelah masuk Jakarta Islamic Index terdistribusi normal dengan menggunakan asumsi Shapiro-Wilk Test.

Tabel 7.2. Uji Normalitas AAR Saham Sebelum dan Sesudah Perusahaan Keluar Dalam Jakarta Islamic Index Periode 2012-2017

\begin{tabular}{|c|c|c|c|}
\hline \multicolumn{4}{|c|}{ Tests of Normality } \\
\hline & \multicolumn{3}{|c|}{ Shapiro-Wilk } \\
\hline & Statistic & $\mathrm{df}$ & Sig. \\
\hline sebelum_keluar & 0,917 & 7 & 0,443 \\
\hline setelah_keluar & 0,953 & 7 & 0,758 \\
\hline & und of the true si & & \\
\hline & ignificance Corre & & \\
\hline
\end{tabular}

Sumber: Hasil olah data menggunakan SPSS (2018)

\section{Interpretasi}

Dari hasil uji normalitas didapatkan hasil bahwa dari nilai sig dalam pengujian Shapiro-wilk, sebagai berikut:

a. setelah masuk memiliki nilai sig 0,443

b. setelah masuk memiliki nilai sig 0,758

jika :

sig $<0,05$ tidak signifikan

sig $>0,05$ signifikan

maka :

a. sebelum keluar sig $0,443>0,05$

b. setelah keluar sig $0,758>0,05$

Dari hasil uji statistik di atas terlihat bahwa pada nilai sig a dan b memiliki nilai lebih besar dari 0,05 yakni 0,443 untuk nilai sebelum keluar dan untuk nilai setelah 
keluar yaitu 0,758 , sehingga dapat ditarik simpulkan bahwa kedua variabel di atas yaitu $A A R$ sebelum masuk Jakarta Islamic Index, dan AAR setelah masuk Jakarta Islamic Index terdistribusi normal dengan menggunakan asumsi Shapiro-Wilk Test.

\section{Pengujian Hipotesis}

Penelitian dalam skripsi ini mengkaji tentang bagaimana reaksi investor terhadap pengumuman perubahan komposisi Jakarta Islamic indeks, yang mana didalam-Nya merupakan saham-saham yang sudah melalui tahap screening dan sudah dinyatakan syariah oleh DSN-MUI dan Jakarta Islamic Index merupakan saham-saham pilihan dari indeks ISSI. Tujuan dari penelitian ini adalah untuk melihat abnormal return yang diperoleh oleh investor akibat dari peristiwa pengumuman perubahan komposisi Jakarta Islamic Index. Jika peristiwa pengumuman perubahan komposisi Jakarta Islamic indeks memiliki kandungan informasi maka investor akan menggunakan informasi tersebut sebagai dasar pembuat keputusan investasi.

Dalam pasar modal, informasi merupakan dasar pengambilan keputusan investasi oleh investor, menurut Fama dalam teorinya tentang Efficient market Hypothesis menyebutkan bahwa pasar dikatakan efisien apabila harga-harga yang ada sepenuhnya mencerminkan (fully reflect) semua informasi yang ada, suatu pasar dikatakan efisien apabila tidak seorang pun baik itu investor ritel, maupun institusi akan mampu memperoleh return tidak normal (abnormal return) setelah di sesuaikan dengan risiko dengan menggunakan strategi yang ada (Gumanti \& Utami, 2002).

Fama membagi pasar efisien menjadi tiga bentuk yakni pasar efisien bentuk lemah, pasar efisien bentuk setengah kuat, dan pasar efisien bentuk kuat. Kemudian Fama menyebutkan bahwa pasar efisien semi kuat sebagai studi peristiwa (Event study) yang artinya harga-harga sekuritas mencerminkan semua informasi publik yang relevan (Fama et al., 1991).

Jika suatu peristiwa mengandung informasi maka investor akan bereaksi terhadap peristiwa tersebut dan akan terlihat dari ada tidaknya abnormal return yang di akibatkan oleh digunakannya informasi tersebut sebagai pedoman bagi investor dalam membuat keputusan investasi.

\section{Pengujian Hipotesis H1}

Tabel 8.1 Hasil Uji Beda Abnormal Return Sebelum dan Sesudah Pengumuman Masuk Jakarta Islamic Index 2012-2017

\begin{tabular}{|l|l|c|r|r|r|}
\hline \multicolumn{7}{|c|}{ Paired Samples Statistics } \\
\hline \multicolumn{2}{|c|}{} & Mean & N & Std. Deviation & \multicolumn{1}{|c|}{ Std. Error Mean } \\
\hline \multirow{2}{*}{$\begin{array}{l}\text { Pair } \\
1\end{array}$} & sebelum_masuk & 0,001286 & 7 & 0,0052891 & 0,0019991 \\
\cline { 2 - 6 } & sesudah_masuk & 0,003729 & 7 & 0,0069670 & 0,0026333 \\
\hline
\end{tabular}

Sumber: hasil uji statistik menggunakan SPSS

Terlihat pada tabel paired sample statistics, untuk nilai sebelum masuk diperoleh rata-rata sebesar 0,0012, sedangkan untuk nilai sesudah masuk diperoleh rata-rata 0,00037. Dengan jumlah data yang dijadikan sampel sebanyak 7 data. Standar deviasi 0,0052 untuk sebelum masuk dan 0,0069 untuk sesudah masuk, dengan standar error mean masing-masing sebesar 0,0019 dan 0,00026. 


\begin{tabular}{|l|l|r|r|r|r|}
\hline \multicolumn{7}{|c|}{ Paired Samples Correlations } \\
\hline $\begin{array}{l}\text { Pair } \\
1\end{array}$ & sebelum_masuk \& sesudah_masuk & & N & \multicolumn{1}{c|}{ Correlation } & Sig. \\
\hline
\end{tabular}

Sumber: hasil uji statistik menggunakan SPSS

Sedangkan pada tabel paired sample correlation memiliki nilai 0,254 dengan nilai sig 0,582 yang berarti tidak berhubungan secara signifikan karna nilai probabilitas $>$ dari 0,05 .

\begin{tabular}{|l|c|c|c|c|c|c|c|}
\hline \multicolumn{9}{|c|}{ Paired Samples Test } \\
\hline
\end{tabular}

Sumber: hasil uji statistik menggunakan SPSS

Tampak terdapat 7 pasang sampel. Kemudian rata-rata selisih setiap pasangan adalah -0,0024 dengan simpangan baku sebesar 0,0076 .selanjutnya dengan paired sample t test menghasilkan nilai t hitung sebesar 0,850 dengan derajat bebas 6 dan sig (2-tailed) sebesar 0,428. Karena nilai sig. (2-tailed) ini lebih besar dari alpha (jika $\alpha=$ $0,05)$ maka dapat disimpulkan bahwa tidak terdapat perbedaan yang signifikan antara abnormal return saham sebelum masuk dengan setelah masuk dari Jakarta Islamic Index. Sehingga hipotesis Ha1 ditolak.

\section{Pengujian Hipotesis $\mathbf{H} 2$}

Tabel 8.2 Hasil Uji Beda Abnormal Return Sebelum dan Sesudah Pengumuman Masuk Jakarta Islamic Index 2012-2017

\begin{tabular}{|l|l|r|r|r|r|}
\hline \multicolumn{7}{|c|}{ Paired Samples Statistics } \\
\hline \multicolumn{2}{|c|}{} & Mean & N & Std. Deviation & Std. Error Mean \\
\hline $\begin{array}{l}\text { Pair } \\
1\end{array}$ & sebelum_keluar & $-0,001000$ & 7 & 0,0031342 & 0,0011846 \\
\cline { 2 - 6 } & setelah_keluar & 0,000714 & 7 & 0,0063046 & 0,0023829 \\
\hline
\end{tabular}

Sumber: hasil uji statistik menggunakan SPSS

Terlihat pada tabel paired sample statistics, untuk nila sebelum keluar diperoleh rata-rata sebesar $-0,0010$, sedangkan untuk nilai sesudah keluar diperoleh rata-rata 0,0007. Dengan jumlah data yang dijadikan sampel sebanyak 7 data. Standar deviasi 0,0031 untuk sebelum masuk dan 0,0063 untuk sesudah masuk, dengan standar error mean masing-masing sebesar 0,0011 dan 0,00023 .

\begin{tabular}{|c|c|c|c|c|}
\hline \multicolumn{5}{|c|}{ Paired Samples Correlations } \\
\hline & & $\mathrm{N}$ & Correlation & Sig. \\
\hline Pair 1 & $\begin{array}{l}\text { sebelum_keluar \& } \\
\text { setelah_keluar }\end{array}$ & 7 & $-0,592$ & 0,162 \\
\hline
\end{tabular}

Sumber: hasil uji statistik menggunakan SPSS

Sedangkan pada tabel paired sample correlation memiliki nilai -0,592 dengan nilai sig 0,162 yang berarti tidak berhubungan secara signifikan karna nilai probabilitas $>$ dari 0,05 . 


\begin{tabular}{|c|c|c|c|c|c|c|c|c|c|}
\hline \multicolumn{10}{|c|}{ Paired Samples Test } \\
\hline & & \multicolumn{5}{|c|}{ Paired Differences } & \multirow[t]{3}{*}{$\mathrm{t}$} & \multirow[t]{3}{*}{ df } & \multirow{3}{*}{$\begin{array}{l}\text { Sig. } \\
(2- \\
\text { tailed) }\end{array}$} \\
\hline & & \multirow[t]{2}{*}{ Mean } & \multirow[t]{2}{*}{$\begin{array}{c}\text { Std. } \\
\text { Deviation }\end{array}$} & \multirow[t]{2}{*}{$\begin{array}{l}\text { Std. Error } \\
\text { Mean }\end{array}$} & \multicolumn{2}{|c|}{$\begin{array}{l}\text { 95\% Confidence Interval } \\
\text { of the Difference }\end{array}$} & & & \\
\hline & & & & & Lower & Upper & & & \\
\hline $\begin{array}{l}\text { Pair } \\
1\end{array}$ & $\begin{array}{l}\text { sebelum_keluar } \\
\text { - setelah_keluar }\end{array}$ & $-0,0017143$ & 0,0085417 & 0,0032285 & $-0,0096141$ & 0,0061855 & $-0,531$ & 6 & 0,614 \\
\hline
\end{tabular}

Sumber: hasil uji statistik menggunakan SPSS

Terlihat bahwa terdapat 7 pasang sampel. Kemudian rata-rata selisih setiap pasangan adalah -0,0017 dengan simpangan baku sebesar 0,0085 .selanjutnya dengan paired sample t test menghasilkan nilai t hitung sebesar -0,531 dengan derajat bebas 6 dan sig (2-tailed) sebesar 0,614. Karena nilai sig. (2-tailed) ini lebih besar dari alpha (jika $\alpha=0,05$ ) maka dapat disimpulkan bahwa tidak terdapat perbedaan yang signifikan antara abnormal return saham sebelum keluar dengan setelah keluar dari Jakarta Islamic Index. Sehingga hipotesis Ha2 ditolak.

\section{PEMBAHASAN}

\section{Hipotesis H1}

Dari hasil pengujian uji beda ( paired sample t-test) menunjukkan bahwa tidak adanya perbedaan abnormal return saham yang signifikan antara sebelum dan sesudah pengumuman masuk Jakarta Islamic Index. Hal tersebut bisa terjadi karna beberapa hal salah satunya adalah bahwa investor sudah mengganggap peristiwa ini sudah biasa terjadi karna terjadi secara periodik, dan efek yang di timbulkan dari perubahan komposisi JII kurang mendapat respons atau sudah bisa di prediksi, seperti terlihat pada grafik di bawah ini.

Grafik 3.1 Nilai Average Abnormal Return masuk

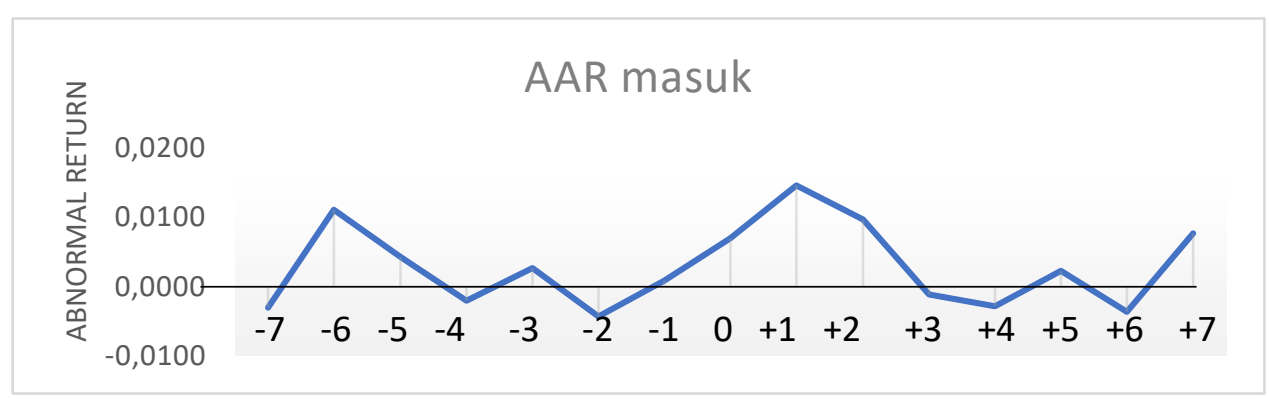

Dari grafik di atas terlihat bahwa reaksi investor mulai terlihat pada $\mathrm{t}-1$, pada t0 dan $\mathrm{t}+1$, pada hari $\mathrm{t}-1$ sudah ada reaksi investor, hal ini mengindikasikan terjadinya kebocoran informasi, kebocoran informasi mengenai perubahan komposisi Jakarta Islamic indeks ini merupakan sesuatu yang dapat diduga mengingat peristiwa seperti ini merupakan peristiwa periodik setiap semester, pada t0 pada peristiwa itu terjadi investor sudah merespons informasi baru tersebut dan memuncak pada $t+1$. Dengan demikian reaksi investor cukup cepat dalam menyerap informasi baru yang muncul, hanya membutuhkan waktu satu hari untuk membentuk harga baru.

Penyerapan informasi pengumuman Jakarta Islamic Index yang tidak membutuhkan waktu lama, hal ini mengindikasikan bahwa adanya distribusi informasi 
yang simetris, ini bertentangan dengan teori asimetris yaitu ketika pasar membutuhkan waktu yang lama dalam bereaksi terhadap suatu informasi atau peristiwa sampai berlarut larut dan cukup lama, hal tersebut disebabkan karna informasi yang belum asimetris

\section{Hipotesis H2}

Dari hasil pengujian uji beda ( paired sample t-test) menunjukkan bahwa tidak adanya perbedaan abnormal return saham yang signifikan antara sebelum dan sesudah pengumuman keluar Jakarta Islamic Index.

Grafik 3.2 Nilai Average Abnormal Return keluar

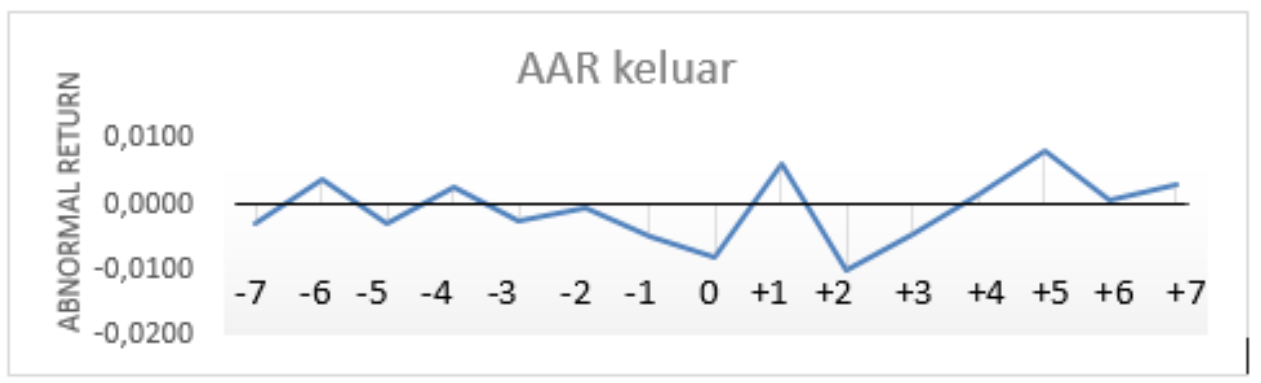

Dari grafik di atas terlihat jelas pada t0 investor langsung bereaksi dengan segera, dengan demikian distribusi informasi sudah mudah di dapatkan investor. Namun pada $\mathrm{t}+1$ terjadi anomali setelah pengumuman terjadi, ada beberapa saham yang tidak terpengaruh oleh negatif effect yang di timbulkan dari dikeluarkannya dari Jakarta Islamic Indeks, apalagi pada $\mathrm{t} 4, \mathrm{t}+5, \mathrm{t}+6, \mathrm{t}+7$ negatif effect sudah tidak ada lagi.

Dilihat pada tabel 4 , pada $\mathrm{t}+1$ ada 4 saham yang mempunyai nilai paling besar yaitu saham PWON (0,1022), TINS (0,0531), ASRI (0,0452), dan ADHI (0,0417). PWON, ASRI, dan ADHI ada dalam satu sektor yang sama yaitu sektor 6 (Property, Real Estate \& Building Construction). Sehingga pada $\mathrm{t}+1$ saham sektor Property, Real Estate \& Building Construction tidak terpengaruh oleh negatif effect yang di akibatkan oleh pengumuman di keluarnya saham tersebut dari Jakarta Islamic Index. Selain itu, terlihat investor sudah mengetahui terlebih dahulu informasi atau terjadi kebocoran informasi terlihat dari ada reaksi dari turunnya nilai AAR pada $\mathrm{t}-2$.

Hal senada yang simpulkan dari penelitian terdahulu mengenai penelitian tentang pasar efisien pada pasar modal Indonesia antara lain seperti pada penelitian yang dilakukan oleh I Gusti Ngurah Agung dan I Gusti Bagus mengenai pengujian efisiensi pasar di bursa efek Indonesia khususnya Indeks Kompas 100 dengan mengambil periode penelitian tahun 2015 yang menyimpulkan bahwa bursa efek Indonesia efisien bentuk setengah kuat secara informasi (Ngurah, Putra, \& Wiksuana, 2017). Kemudian penelitian yang dilakukan oleh Rahman Hakim dengan periode penelitian 2011-2013 menghasilkan bahwa pasar modal Indonesia terutama dalam Jakarta Islamic indeks ditemukannya pasar efisien bentuk setengah kuat dengan tidak ditemukannya abnormal return yang signifikan (Hakim, 2015). 


\section{KESIMPULAN, KETERBATASAN DAN SARAN}

Penelitian ini bertujuan untuk mengetahui dan menganalisis pasar efisien bentuk setengah kuat pada pengumuman Jakarta Islamic Index, perbedaan rata-rata perbedaan rata-rata abnormal return sebelum dan sesudah pengumuman pada saham-saham perusahaan yang masuk ke dalam Jakarta Islamic Index periode 2012-2017 dan perbedaan rata-rata perbedaan rata-rata abnormal return sebelum dan sesudah pengumuman pada saham-saham perusahaan yang keluar dari Jakarta Islamic Index periode 2012-2017.

Berdasarkan analisis data dan pembahasan pada 49 saham yang masuk dan keluar dari Jakarta Islamic Index selama periode pengamatan 15 hari bursa, maka dapat ditarik kesimpulan sebagai berikut:

1. Dari hasil uji Paired Sample T-Test pertama, menghasilkan tidak terdapat perbedaan rata-rata abnormal return positif dan signifikan pada pengumuman masuk Jakarta Islamic Index pada taraf siginifikansi 5\% (Ha1 ditolak) .

2. Hasil uji yang kedua juga menghasilkan tidak terdapat perbedaan rata-rata abnormal return negatif dan signifikan pada pengumuman keluar Jakarta Islamic Index pada taraf signifikansi 5\% (Ha2 ditolak).

Dalam kaitan hipotesis pasar efisien dapat dikatan bahwa pada Jakarta Islamic Index periode 2012-2017 sudah pada bentuk pasar efisien bentuk setengah kuat secara informasi

\section{Saran}

Dengan segala keterbatasan yang ada dalam penelitian ini maka peneliti menyarankan apabila ada peneliti lain yang akan meneliti hal yang sama dengan penelitian ini yaitu sebagai berikut:

1. Perlunya alat ukur yang ketat dalam proses screening apabila menggunakan periode tahun penelitian yang panjang.

2. Peneliti juga disarankan melakukan pengamatan terhadap variabel lain selain variabel abnormal return saham, atau menambah variabel lain, terutama untuk menguji efisiensi pasar

3. Untuk penelitian selanjutnya diharapkan mempertimbangkan menambah faktor lain selain corporate action untuk meningkatkan keakuratan variabel penelitian maka diperlukannya memperhatikan kondisi makro ekonomi, keadaan politik, dan kondisi sektor masing-masing industri.

\section{DAFTAR PUSTAKA}

Darmadji, T., \& Fakhrudin, H. (2008). Pasar Modal di Ondonesia : Pendekatan Tanya Jawab. JAkarta : Salemba Empat.

Dewan Syariah Nasional. (2003). Pasar Modal dan Pedoman Umum Penerapan Prinsip Syariah di Bidang Pasar Modal, 1-8.

Dwi Sari, M. (2016). History of Islamic Bank in Indonesia: Issues Behind Its Establishment. International Journal of Finance and Banking Research, 2(5), 178.

Fama, E. F., Booth, D., Bradley, M., Brennan, M., Buser, S., Campbell, J., ... Warner, J. (1991). Efficient Capital Markets: II The comments of Fischer Black. The 
Journal of Finance *, XLVI(5), 1575-1617.

Fame, E. F. (2010). Efficient capital markets: a review of theory and empirical work. The Journal of Finance, 25(2), 383-417.

Gumanti, T., \& Utami, E. (2002). Bentuk Pasar Efisiensi Dan Pengujiannya. Jurnal Akuntansi Dan Keuangan, 4, 54-68.

Hakim, R. (2015). Analisis Reaksi Pasar Terhadap Pengumuman Perubahan Komposisi Jakarta Islamic Index Periode 2011-2013. UIN Sunan Kalijaga.

Haryono, S. (2015). Asimetri informasi dalam transaksi perbankan syariah di Indonesia. Ijtihad, 1(15), 103-118.

Hendrayadi, S. (2015). Metode Riset Kuantitatif : Teori dan Aplikasi pada Penelitian Bidang Managemen dan Ekonomi Islam. Jakarta: Prenadamedia Grup.

Jogiyanto. (2010). Studi peristiwa: menguji reaksi pasar modal akibat suatu peristiwa. BPFE Jogjakarta.

Krichene, N. (2013). Islamic Caital Markets Theory and Practice. Willey Finance.

Kurtosis, S. (n.d.). Perbandingan Tingkat Konsistensi Normalitas Distribusi Metode, $127-135$.

Nasution, Y. S. J. (2015). Hypothesis Pasar Efisien / Efficient Market Hypothesis ( Pasal Modal menurut Teori Fama dan Pandangan Islam ). Jurnal Perspektif Ekonomi Darussalam, 1(1), 25-43.

Ngurah, I. G., Putra, A., \& Wiksuana, I. G. B. (2017). Pengujian Efisiensi Pasar Di Bursa Efek Indonesia. Jurnal Manajemen Unud, 6(4), 2105-2132.

Oktaviana, U. K., \& Wahyuni, N. (2011). Pengaruh Perubahan Komposisi Jakarta Islamic Index Terhadap Return Saham. Jurnal EL-QUDWAH, 1(April 2011), 121.

Susilowati, Y., \& Turyanto, T. (2011). Reaksi Signal Rasio Profitabilitas dan Rasio Solvabilitas Terhaadap Return Saham Perusahaan. Dinamika Keuangan Dan Perbankan, 3(1), 17-37. 